\title{
New Characteristics of China's Outward FDI Since 40 Years of Reform and Openness
}

\author{
Liu Zhiyuan \\ Department of International Economics and Trade, \\ Business School, Beijing Language and Culture University, \\ Beijing, China \\ liuzhiyuan@blcu.edu.cn
}

\begin{abstract}
After 40 years of opening up and development, China has become the second largest investor in the world. This article tries to summarise the new characteristics of China's OFDI based on its recent performance to present an overview of Chinese OFDI and to predict the future development trend of Chinese OFDI. We first divide the development phases of Chinese outward FDI into four stages and introduce the main characteristics of each stage. Then we analyse new development characteristics of Chinese OFDI from three aspects. Finally we explain the three major challenges facing Chinese OFDI and estimate the future development trends of Chinese OFDI.
\end{abstract}

\section{Keywords-China; Outward FDI; Characteristics; Challenges}

\section{INTRODUCTION}

Outward FDI (OFDI) is an important component of China's "going global" strategy. It is one of the best measures to safeguard China's national economic security, actively respond to the challenges brought by economic globalization, avoid trade barriers, participate in international division of labour and receive foreign advanced technology and management experiences as well as timely grasp of external information.

China's OFDI, which stated 40 years ago, has gone through a bumpy road and achieved positive progress. Since entering the new century, especially as China's rapid economic development and increased comprehensive national strength, China's OFDI has sprung up, sustained and rapid expanded to global. With the improvement of Chinese enterprises' international operation skills and perfection of government supportive policy, after 40 years of reform and openness, China's OFDI has entered into a new era. In 2015, China's OFDI for the first time exceeded China's inward FDI, realizing the net outflow of capital under the financial account. In 2016, China's OFDI flows reached $\$ 196.15$ billion, ranked number 2 in the world, right after United States. In the first two months of 2018, China's OFDI flows are $\$ 16.82$ billion, with a yearon-year growth of more than $25 \%$.

\section{THE DEVELOPMENT PROGRESS OF CHINA's OFDI}

\section{A. Spontaneous Exploration Stage (1978-1991)}

China's OFDI developed gradually after the reform and openness from 1978. In August 1979, the state council promulgated 15 economic reform measures, of which the $13^{\text {th }}$ item explicitly allowed enterprises to operate abroad, and for the first time defined OFDI as a policy. In November 1979, Beijing Friendship Business Services Company and Japan Itochu Corporation cooperated and set up the first joint venture in Tokyo. During the early time of reform and openness, expanding export and foreign capital utilization are the main objective. Only few companies set up foreign operation according to their own need, in order to provide services for international trade. In the early 1980s, some large enterprises began to explore OFDI.

Generally speaking, enterprises involved in OFDI activities during the first stage are relatively small. From 1978 to 1984 Chinese enterprises established 113 non-trading companies abroad, with a total investment of more than $\$ 200$ million. The main foreign investors are the central and local government controlled international trade companies, or the international economic corporation companies owned by the province and city governments, such as China National Chemicals Import and Export Corporation (now is named as "SinoChem Group"), China National Metals and Minerals Import and Export Corporation (now is named as "China Minmetals Corporation"), and so on. The investment field mainly focuses on catering, contracting construction, consulting services, trade and other service industries. Investment is mainly distributed in Hong Kong, Macao and the surrounding developing countries.

From 1985 to 1987, the first boom of Chinese OFDI activities is emerged. Chinese OFDI reached $\$ 1.3$ billion, six times of that of previous 7 years combined. A total of 124 foreign enterprises have been established, more than the total of that of previous 7 years. During the period of 1988 to 1991 , there were 735 non-trading enterprises established foreign operations, with a total investment of $\$ 2.944$ billion. The growth rate of OFDI stock reached $35 \%$. The main investors have expanded to large and medium-sized production enterprises and comprehensive financial enterprises, such as Shougang Group and China International Trust and Investment Corporation (CITIC Group). The investment field is gradually 
extended to more than 20 industries, including resource development, manufacturing and processing, and transportation. Moreover, the investment locations have been extended to some developing countries.

\section{B. Initial Stage (1992-2001)}

From 1992 to 1998, China has entered into the economic adjustment and recovery period. The government carried out an overall clean-up and rectification to the investment abroad, and strict examination and approval procedures of OFDI. During this period, Chinese overseas investment flow is $\$ 25.286$ billion, and the OFDI stock growth rate down to $16 \%$.

In 1998, it was proposed at the second plenary session of the $15^{\text {th }}$ Communist Party of China Central Committee that, while actively expand exports, the government will systematically organize and support a number of state-owned enterprises to go out, making investment in Africa, Central Asia, the Middle East, Central and South America and many other places. In February 1999, the state council carry out "Opinions on Encouraging Enterprises to Carry out Overseas Processing and Assembly Business with Materials", which laid the foundation for China's strategy of "going out". Subsequently, the relevant department under the state council formulated the specific supporting documents of implementation, perfected the management system of foreign direct investment. In 2001, China's foreign direct investment presented a fast growth, reaching $\$ 6.885$ billion, 7.5 times of that in 2000 .

Outward direct investment of China has achieved dramatically success during this period, especially fruitful overseas processing trade and overseas resources exploitation. The main investor of Chinese OFDI began to diversify. Private companies, such as Wanxiang Group and Goodbaby Group, gradually began to try to start their overseas business. By the end of 1992, China had established 4,117 enterprises in more than 120 countries and regions. By 2001, it had expanded to over 160 countries and regions. Investment industry shifts from trade services to resource exploitation and production and manufacturing. By the end of 2001, $44 \%$ of Chinese OFDI goes to the production industry, and to a certain extent, improved the previous trade dominant investment structure.

\section{Accerlerated Development Stage:2002-2008}

From 2002, China's OFDI began to enter a new stage of growth. In December 2001, China has joined WTO, which marks a new era of OFDI development in China. At this stage, the governments speed up the implementation of the strategy of "going out", encourage and support all kinds of enterprises to operate internationally, and participate in international economic and technical cooperation actively. In 2004, the ministry of commerce issued "Provisions on Approval of Overseas Investment and Establishment of Enterprises Abroad", simplified the procedures and created a good service environment for OFDI. At the same time, the government also published varies of investment guidance catalogue to help the enterprises' foreign investment activities. Moreover, the enterprises are also receiving supports from the government through financial subsidies and long-term low-interest loans. All these measures have contributed to the OFDI of Chinese companies.
After the implementation of exchange rate reform in July 2005, with the appreciation of RMB, China's OFDI showed a rapid growth. By 2007, China's OFDI reached \$26.51 billion, accounting for $1.33 \%$ of world and $10.5 \%$ of developing countries OFDI respectively. Benefit from the appreciation of the RMB, improvement in capital market development, and growing Chinese enterprise strength, coupled with revising of the Law of People's Republic of China on Foreign Exchange Control Regulations in 2008, China's OFDI exceeded 50 billion US dollars, reaching $\$ 55.91$ billion with an increase of 93.3\% year-on-year, ranked number 12 in the world as the major investing country.

\section{Hyper Development Stage: 2009-now}

From 2009, China's OFDI showed an even more strong momentum of development. Due to the international financial crisis, developed countries experienced a slow recovery while economic growth in China keeps rocking. According to the Statistical Bulletin of China's Outward Foreign Direct Investment, China has become the 5th largest investing country in the world in 2009. During the period of 2011 to 2015, China's OFDI totalled $\$ 539.08$ billion.

In 2015, China's OFDI reached to a historical high of $\$ 145.67$ billion, with a year-on-year increase of $18.3 \%$. The scale of China's OFDI flows ranked only behind the United States and exceeded Japan to become the second in the world. Moreover, in 2015, for the first time, China's OFDI exceeded inward FDI, entering a period of net capital outflow [1]. In 2016, China OFDI reached $\$ 196.15$ billion, with an average growth rate of $34.7 \%$, and remains the second position in the world. More than 24.4 thousand companies have set up foreign subsidiaries and operations in 109 countries and regions in the world.

At this stage, merger and acquisition (M\&A) becomes the major method of ODI. In 2016, Chinese enterprises complete 765 projects, involving 74 countries and regions, and the actual transaction amount reached $\$ 135.33$ billion. The acquisition of $100 \%$ stake of Nanyang Commercial Bank by China Cinda Asset Management Company for 8.88 billion US dollars is the largest overseas M\&A project carried out by Chinese enterprises in 2016. Chinese enterprises M\&A involves 18 industries, including manufacturing, software and information technology services, transportation and postal service, power, heat, gas and water production and supply industry and so on.

\section{NEW CHARACTERISTICS OF CHINA'S OFDI}

In 2017 , the recovery of the world economy still remains fragile, while China's economy continues to grow healthily, becoming a major driver and stabilizer of world economic growth. With the support of government and the construction of "One Belt, One Road" initiative, Chinese enterprises become the new representatives of emerging economies' multinational corporations [2]. China's outward investment has shifted from hyper development stage to high quality development stage, further consolidating its position as a major investor. However, with the great succeed in OFDI, Chinese enterprises also encountered sharply rising obstacles when they making investment around the world. From 2016 to 2017, there have been more than 340 trade remedy investigations against 
Chinese enterprises, including anti-dumping, countervailing, and safeguard measures. Therefore, some new characteristics of Chinese OFDI have emerged.

\section{A. Outward FDI Flows Fell for the First Time}

In 2017, the outflows of FDI from Chinese MNEs were down for the first time since 2002, with a decrease of $36 \%$ to $\$ 124.6$ million [3]. Table 1 presents the flows and world rankings of Chinese OFDI from 2002 to 2017. During the past 15 years, Chinese OFDI shows a rapid growth at the average annual rate of $35.8 \%$. In 2016, even the world total OFDI decreased by $18 \%$ in total, China's OFDI grows at the rate of $34.7 \%$. However, as a result of policies clamping down on Chinese OFDI by some developed countries, China's OFDI decreased sharply.

TABLE I. OUTWARD FDI FLOWS OF CHINA, 2002-2017

\begin{tabular}{|l|c|c|c|}
\hline \multirow{2}{*}{ Year } & \multicolumn{3}{|c|}{ Outward FDI Flows (Billions of dollars) } \\
\cline { 2 - 4 } & Amount & World Ranking & Year on Year Growth Rate (\%) \\
\hline 2002 & 2.70 & 26 & 5.6 \\
\hline 2003 & 2.85 & 21 & 93.0 \\
\hline 2005 & 5.50 & 20 & 122.9 \\
\hline 2006 & 12.26 & 17 & 43.8 \\
\hline 2007 & 21.16 & 13 & 25.3 \\
\hline 2008 & 26.51 & 17 & 110.9 \\
\hline 2009 & 55.91 & 12 & 1.1 \\
\hline 2010 & 56.53 & 5 & 21.7 \\
\hline 2011 & 68.81 & 5 & 8.5 \\
\hline 2012 & 74.65 & 6 & 17.6 \\
\hline 2013 & 87.80 & 3 & 22.8 \\
\hline 2014 & 107.84 & 3 & 14.2 \\
\hline 2015 & 123.12 & 3 & 18.3 \\
\hline 2016 & 145.67 & 2 & 34.7 \\
\hline 2017 & 196.15 & 2 & -36.5 \\
\hline
\end{tabular}

\section{B. “One Belt, One Road” Initiative Construction Made} Remarkable Achievements

"One Belt, One Road" initiative have been brought forward for many years, and it has received positive responses from more than 140 countries and more than 80 international organizations. More than 50 countries have signed relevant cooperation agreements with China. From 2014 to 2016, China's OFDI in countries along the "One Belt, One Road" reached US\$ 48 billion, and the investment industry is increasingly diversified, while mergers and acquisitions continue to be active [4].

In 2017, Chinese enterprises made direct investment of $\$ 14.36$ billion in countries along "One Belt, One Road" initiative, accounting for $12 \%$ of the total amount of the same period, increased by $3.5 \%$ compared with previous year. Major destination includes Singapore, Malaysia, Laos, Indonesia, Pakistan, Vietnam, Russia, and the United Arab Emirates. 62 M\&A projects have been implemented, worth up to 8.8 billion US dollars, increased by $32.5 \%$ year on year. Moreover, Chinese enterprises have signed 7,217 new contracts for foreign contracted projects in 61 countries along "One Belt, One Road" initiative, with 144.32 billion US dollars in newly signed contracts, accounting for 54.4 per cent of China's new contracts for foreign contracted projects, with a year-on-year growth of $14.5 \%$.

\section{The Improvement of Quality of Chinese OFDI}

In the past five years, China has consistently led the world in foreign investment, gradually improved its new open economy system and made major achievements in business development. China's initial emergence as a major economic and trade power has laid a solid foundation for building itself into a strong economic and trade power. The improvement of the quality of foreign investment has strongly supported the transformation from a major economic and trade power to a strong economic and trade power.

\section{1) Irrational investment has been cubed}

In 2017, irrational foreign investment has been effectively countered and contained. In late 2016, the Chinese Government identified several areas of "irrational investment" and started to curb overseas investments, especially M\&As, in certain industries, including real estate, hotels, cinemas, entertainment and sport clubs. Accordingly, OFDI in these industries shrank by more than four-fifths in 2017.

The government has supported strong and powerful enterprises with good reputation to "go global", strengthens the inspection of the authenticity and compliance of foreign investment. The number of M\&A in the real economy and emerging industries, such as chemical industry, electric power industry and robot manufacturing industry, has increased. China's foreign investment cooperation have achieved sound and standardized development in 2017. Remarkable progress have been made in industrial structure optimization, foreign 
investment and acquisition, new projects for contracting projects, and overseas economic and trade cooperation zones.

2) Chinese OFDI accelerated flows to Americas and Europe

China's OFDI flows to the Americas and Europe are speeding up in 2016, of which \$27.23 billion to Latin America, increased by $115.9 \%$ from a year earlier, $\$ 20.35$ billion to North America, increased by $89.9 \%$, and $\$ 10.69$ billion to Europe, increased by $50.2 \%$ compared with previous year, as indicated in Figure 1.

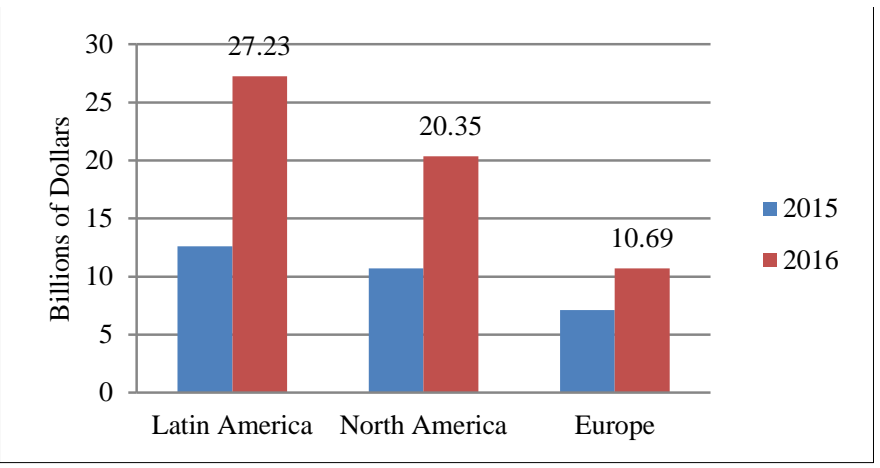

Fig. 1 Major Destinations of Chinese OFDI (Billions of Dollars)

Investment in Latin American accounted for $13.9 \%$ of China's OFDI flow, investment in North America accounted for $10.4 \%$ of China's total OFDI. United States and Canada are the major destinations of Chinese OFDI, with investment flows increased by $111.5 \%$ and $83.7 \%$ year-on-year respectively. China's investment in Europe is accounted for $5.4 \%$ of total, and mainly flows to Germany, Luxembourg, France and UK.

3) China's cross-border M\&As concentrate on service sector

In terms of the industry distribution of China's overseas M\&As, cross-border M\&As of $\$ 97.05$ billion flows to the service sector in 2016, accounting for 71.7 per cent of the total, ranking first. $M \&$ As in manufacturing industry decreased to $\$ 30.11$ billion, accounting for only $22.2 \%$. The share of Chinese cross-border $\mathrm{M} \& \mathrm{As}$ in primary goods sector, including agricultural, forestry, fishery and mining industries, reached US $\$ 8.17$ billion, accounted for only $6.0 \%$.

\section{4) Investment body has been further optimized}

In China's non-financial OFDI flows in 2016, the domestic investors controlled by non-public economy, made foreign direct investment about 123.24 billion US dollars, accounting for $68 \%$ of the total. The state-owned or controlled investors invested about $\$ 57.99$ billion in the world, accounted for $32 \%$ of the total. The non-public economy has become the main body of China's non-financial outward investment. By the end of 2016, state-owned enterprises accounted for 54.3 per cent of China's non-financial FDI stock, increased by 3.9 per cent compared with the end of 2015. Non-state-owned enterprises account for 45.7 per cent, roughly the same as the foreign investment undertaken by state-owned enterprises.

\section{The MAJOR CHANLLENGES OF CHINESE OFDI}

\section{A. Chinese Multinationa Enterprises Are Still Young}

In recent years, Chinese multinational enterprises have achieved a great success in the world, however, their development and experiences have not been recognized nor praised by the international academia. Many experts believe that those Chinese multinational enterprises depend too much on the local talent, indicating a lack of core competitiveness, international operational capacity and the ability to cope with the economic crisis.

According to the China Enterprise Confederation (CEC), in 2016, the world's largest 100 multinational companies' average overseas revenues, overseas assets, and ratio of overseas employees are $64.21 \%, 61.96 \%$ and $56.87 \%$ respectively, while China's top 100 multinational enterprises' corresponding numbers are $19.71 \%, 15.55 \%$ and $7.64 \%$ respectively, indicating a relatively low level of internationalization. Moreover, Chinese Multinational Enterprises also show a significant gap with MNEs from developed countries in terms of per capita assets, sales volume and many other performance indicators. Overall, there is still a long way for Chinese MNEs to go in the future.

\section{B. Global Governance Rules and Methods Lag Behind}

Global development is still unbalanced, the North-South development gap are widening. Frequent regional turbulences, giant fluctuation in price of bulk commodity, disorder of international finance, and many other global issues, become more prominent. The existing international governance system is not representative enough, and in many cases it is still in a state of "separate governance" and cannot form synergy. The fragmentation of governance has led to the lack of solutions to many global problems, providing a living space for the antiglobalization movement. The international community has strengthened supervision and control of foreign direct investment in terms of compliance, fiscal and taxation, and Chinese OFDI stand in the breach.

\section{Chinese OFDI Faces Increasing Risk from Host Countries}

Geopolitics, the replacement of political parties, anti-China public opinion, and other factors all increase the risk of Chinese enterprises investing in foreign projects. The obstacles that Chinese MNEs have to face increased and diversified, such as market access restrictions, national security review, the antitrust review, the enterprise $\mathrm{M} \& \mathrm{~A}$ regulations, labour protection, engineering standards, environmental protection and so on. For example, in 2017, the Committee on Foreign Investment in the U.S. (FIUS), the UK's Financial Conduct Authority (FCA) and the Prudential Regulation Authority (PRA) reviewed a number of M\&A and Greenfield investment planed by Chinese companies. Germany, France and Italy proposed to the European Commission to create a new security review agency, similar with FIUS, to strengthen the scrutiny of foreign investment form China and some other countries. 


\section{CONCLUSION}

After 40 years of implementing "open up" policy, the Chinese OFDI has achieved a great success, especially after the brought forward of "One Belt, One Road" initiative in recent years, Chinese multinational enterprises have encountered new development opportunities, and many new characteristics have been emerged. Although Chinese OFDI faces a great many of challenges, we still believe that Chinese OFDI will show a healthy and continuously development.

In the context of sustained recovery of the world economy, emerging economies and developing countries will become the major driving force behind the strong recovery of the global economy, especially China. With the accelerated development of the open up economic policy, and the orderly construction of "One Belt, One Road" initiative, China's economy will grow steadily, and the outward foreign direct investment will continue to have a rapid development. Furthermore, Chinese multinational corporations will also achieve a great success in the future and the regional distribution will be more diversified.

\section{ACKNOWLEDGMENT}

This research project is supported by Science Foundation of Beijing Language and Culture University (supported by "the Fundamental Research Funds for the Central Universities"), approval number is 17PT04.

\section{REFERENCES}

[1] Fan Zhai, , "China's belt and road initiative: a preliminary quantitative assessment",Jouranl of Asian Economics, vol.55, pp. 84-92, 2018.

[2] J. Du and Y.Zhang, "Does One Belt One Road initiative promote Chinese overseas direct investment?", China Economic Review, vol. 47, pp.189-205, 2018.

[3] UNCTAD, World Investment Report 2018: Investment and New Industrial Policies. New York and Genea,United Nations, 2018.

[4] 2016 Statistical Buletin of China's Outward Foreign Direct Investment. Beijing: China Statisitcs Press, 2017. 